\title{
Histological Study on the Effects of Sofosbuvir and/or Ribavirin on Normal Rats
}

Gamal A. Abdallah, Kadry A. Elbakry, Naglaa F. Elarabany, Seeg A. Altamtam

Zoology Department, Faculty of Science, Damietta University.

Received: 2 October 2016 /Accepted: 16 November 2016

*Corresponding author: kadrym@du.edu.eg

\begin{abstract}
The present study was conducted to demonstrate the histological effects of ribavirin and/or sofosbuvir on liver and kidney of rats. Rats were treated with ribavirin $(0.0227 \mathrm{mg} / \mathrm{kg}$ body weight $)$, sofosbuvir $(0.01 \mathrm{mg} / \mathrm{kg}$ body weight $)$ and mixture of ribavirin and sofosbuvir for 12 weeks. Liver and kidney were stained with H/E stain. Liver tissue also stained with AgNORs stain. The results showed that no histological alteration or abnormal counts were observed after treatment with ribavirin and / or sofosbuvir. Also the count of AgNORs is non-significantly differs between the normal non-treated rats and those treated with ribavirin and/or sofosbuvir. The present study concluded that, treatment with ribavirin and / or sofosbuvir or both has no side effects on normal rats.

Keywords: HCV- sofosbuvir- ribavirin- liver- kidney.
\end{abstract}

\section{Introduction}

Hepatitis $\mathrm{C}$ virus (HCV) infection exhibits a very important medicinal services load, with 184 million individuals influenced around the world (Mohd Hanafiah et al.2013). An expected 185 million individuals are living with hepatitis $\mathrm{C}$ virus infection worldwide and up to 500,000 deaths are caused by the infection every year (Mohd Hanafiah et al 2013; Lozano et al. 2012). In spite of the fact that there is no protective immunization against $\mathrm{HCV}$, current treatments give high cure rates, which are required for development of more powerful therapies (Schmidt et al.
2014). This has brought guarantee that $\mathrm{HCV}$ can be wiped out or more adequately averted by treating patients with hepatitis $\mathrm{C}$, a supposed treatment as prevention methodology (Martin et al. 2013). However, there are serious challenges, including access to HCV testing, care and treatment services (Yehia et al. 2014; Lemoine et al. 2013). Moreover, the danger of re-infection after effective treatment, which is common among injection drug users (IDU), should also be taken into consideration (Grebely $\boldsymbol{e t} \boldsymbol{a l}$. 2012). In Egypt, hepatitis $\mathrm{C}$ virus (HCV) infection is a main reason of chronic liver disease and the most well-known sign for 
liver transplantation (National Institutes of Health, 1997; Detre et al. 1996). Interferon alfa (IFN- $\alpha$ ) was the main treatment accessible for patients with chronic hepatitis $\mathrm{C}$ for a long time. Nonetheless, following 48 weeks of treatment, serum HCV RNA levels are very low in only 15 to 20 percent of patients (Hoofnagle and Di Bisceglie, 1997; Tine et al. 1991; Poynard et al. 1996; Poynard et al. 1996; Lin et al. 1995; Carithers and Emerson. 1997). Pilot investigations of patients who have relapsed and of previously untreated patients suggest that a combination of interferon and ribavirin is more successful treatment than using interferon alone (Schvarcz et al. 1995; Schalm et al. 1997). For already untreated cases, using interferon and ribavirin together for six months was more effective than interferon alone (Reichard et al. 1998).

Ribavirin (Virazole, 1_b-Dribofuranozyl-1, 2, 4-triazole-3carboxamide) is a C-nucleoside analogue known for its powerful affect against a wide range of DNA and RNA viruses (Smith and Wade, 1986). Moreover, it exhibits a medium affinity for adenosine A1 receptors (Franchetti et al., 1995), which have been distinguished in numerous areas of the brain, including the basal ganglia (Rivkees et al. 1995; Ochiishi et al., 1999) which is responsible of the regulation of motor activity.

Sofosbuvir commercially had known as SOVALDI, a strong, once every day, orally administered nucleotide analog inhibitor of the hepatitis $\mathrm{C}$ virus (HCV) NS5B polymerase. Sofosbuvir powerfully suppress genotype 1-6 HCV RNA replicons in vitro, has a high genetic barrier to resistance, and has shown a strong virologic reaction (SVR) rates when used with ribavirin to patients with chronic genotype 2 and 3 HCV infection and with pegylated interferon ribavirin to cases with chronic genotype $1,2,3,4$, or $6 \mathrm{HCV}$ infections. The sofosbuvir/ribavirin or sofosbuvir/pegylated-interferon/ ribavirin therapy gives significantly shorter treatment periods. The present study aimed to evaluate the effects of sofosbuvir and ribavirin and ribavirin/ sofosbuvir mixture on liver and kidney histology of normal rates

\section{Materials and Methods}

A total of 32 female albino rats (weighing about $180 \pm 10 \mathrm{~g}$ ) were used for the experimental study. Animals were purchased from Abu Rawash (Cairo, Egypt). Rats were housed in the animal house in Zoology Department, Faculty of Science, Damietta University, New Damietta, Egypt. They were housed in plastic cages under controlled temperature. They were fed on standard pellet diet. Experiments were started after the animals were allowed to adapt for 2 weeks. After adaptation, rats were divided into 4 groups of each of 8 rats.

\section{Control Group:}

Fed on basal diet and served as a control group.

\section{Ribavirin Group:}

Given dose $(0.0227 \mathrm{mg} / \mathrm{kg}$ body weight $)$ one time/ day administered by stomach gavage for 12 weeks. Sofosbuvir Group: given dose $(0.01 \mathrm{mg} / \mathrm{kg}$ body weight $)$ one time/ day administered by stomach gavage for 12 weeks.

\section{Sofosbuvir-ribavirin group:}

Given a combination of both sofosbuvirribavirin administered by stomach gavage according to previous doses one time/ day for 12 weeks. Liver and kidney tissues, from all groups, were collected directly after scarifying the animal, washed by saline solution and fixed in $10 \%$ formalin. Paraffin blocks were formed and sections were cut at $5 \mu \mathrm{m}$. for histopathological studies,

\section{-Haematoxylin/Eosin stain:}

The method was done according to Drury and Wallington (1967).

\section{-AgNORs Stain:}

The method was done according to Crocker and Nar (1987). Briefly, dewaxed sections were incubated with silver staining mixture ( 1 volume of gelatin at $2 \mathrm{~g} / \mathrm{dl}$ in $\mathrm{lg} / \mathrm{dl}$ formic acid and volumes $50 \mathrm{~g} / \mathrm{dl}$ aqueous silver nitrate solution). The 
staining was done at room in dark for about $40 \mathrm{~min}$. from each section (liver or kidney) the nuclear organizer regions of 50 cells were calculated and the average of each group was calculated.

\section{Results:}

H/E stain:

\section{1-Liver}

Fig (1) showed that the liver of the control rats is composed of numerous hepatic lobules with indistinct outlines. Each lobule possesses a central vein and consists of hepatic strands of cells, these strands or cords anastomose with each other and enclose minute blood sinusoid. The hepatocytes are arranged in sponge-like plates one cell thick and appeared polygonal with centrally located nuclei. The lymphocytes are seen distributed throughout the hepatic tissue. The sinusoidal endothelium is formed of hardly distinct undifferentiated lining cells and the phagocytic Kupffer cells. The latter are distinctly large with oval nuclei. After treatment with ribavirin and/ or sofosbuvir no damage or alteration in liver tissue were observed (Fig 2,3 and 4).

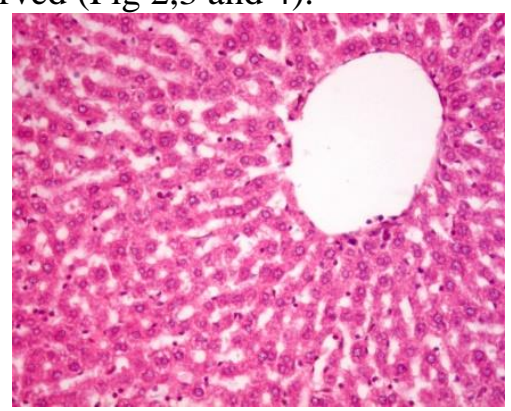

Fig (1): Photomicrograph of rat liver of the control group showing the normal architecture of the liver (H/E. X200)

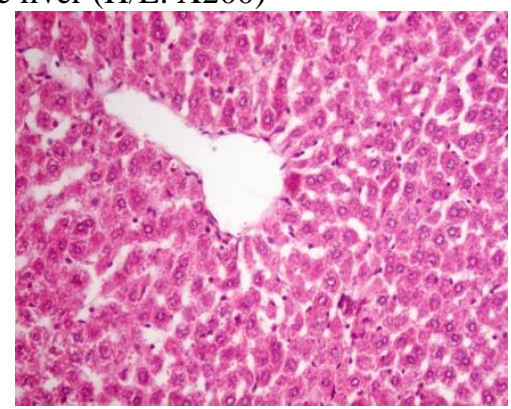

Fig (2): Photomicrograph of rat liver of the ribavirin group showing normal architecture of the liver (H/E. X200)

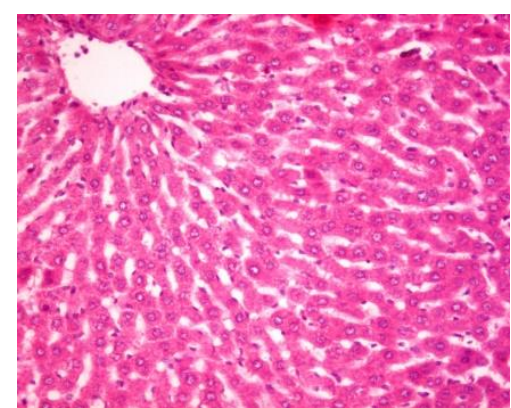

Fig (3): Photomicrograph of rat liver of the sofosbuvir group showing normal architecture of the liver (H/E. X200)

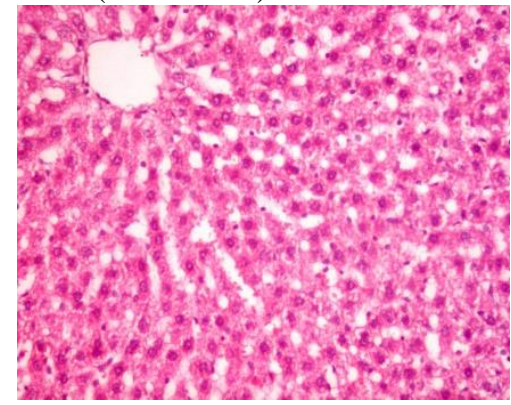

Fig (4): Photomicrograph of rat liver of the ribavirin/sofosbuvir mixture group showing normal architecture of the liver (H/E. X200)

\section{2-Kidney:}

Fig (5) showed the control of the kidney. In this figure, kidney is a compound tubular gland enclosed by a firm connective tissue capsule. The kidney is differentiated into; an outer cortex and an inner medulla. The uriniferous tubules are the structural and functional units of the kidney. The uriniferous tubule consists of Malpighian corpuscles, proximal convoluted tubule, Henele's loop and distal convoluted tubule. The cortex consists of Malpighian corpuscles and both proximal and distal convoluted tubules while the medulla consists mainly of the Henele's loop. The collecting tubules, however, are located in both cortical and medullar regions. In the cortex, numerous renal corpuscles are arranged in parallel rows at right angle to the capsule. Each renal corpuscle is roughly spherical in shape and consists of the Bowman's capsule enclosing the glomerulus, a tuft of blood capillaries. The proximal and distal convoluted tubules are lined with typical thick cubic epithelium. They have relatively regular distinct lumina. At light microscopic level, the control kidney is composed of the cortex and medulla. The cortex is distinguished by renal corpuscles, surrounding by an outer 
envelope of simple squamous epithelium forming the Bowman's capsule and leaving a Bowman's space. The glomerular capillary loop is thin and delicate. The proximal and distal convoluted tubules showed normal lining epithelium and tubular lumina. In rats treated with ribavirin and /or sofosbuvir, the histology of the kidney is normal and no changes were observed (fig 6, 7 and 8 respectively).

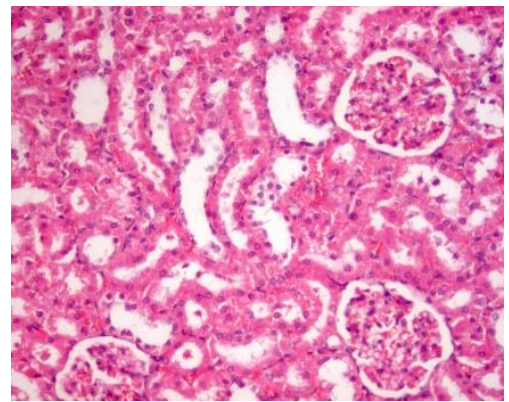

Fig (5): Photomicrograph of rat kidney of the control group showing the normal architecture of the liver (H/E. X200)

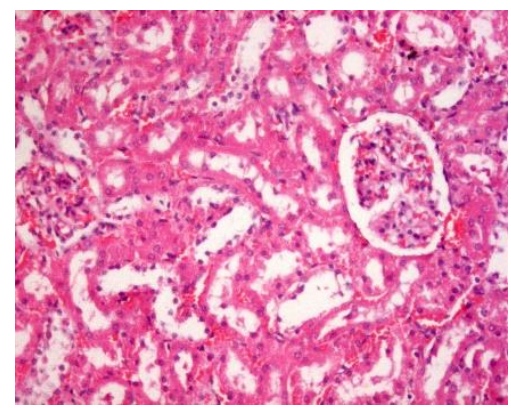

Fig (6): Photomicrograph of rat kidney of the ribavirin group showing the normal architecture of the liver (H/E. X200)

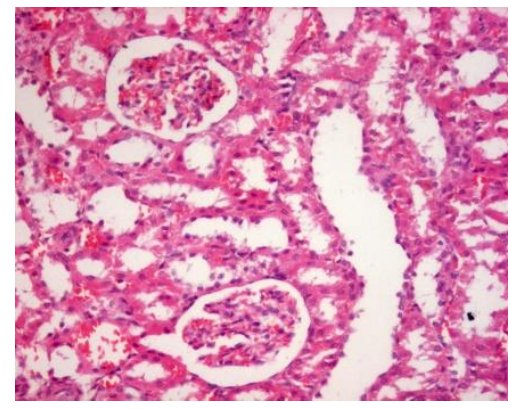

Fig (7): Photomicrograph of rat kidney of the sofosbuvir group showing the normal architecture of the liver (H/E. X200)

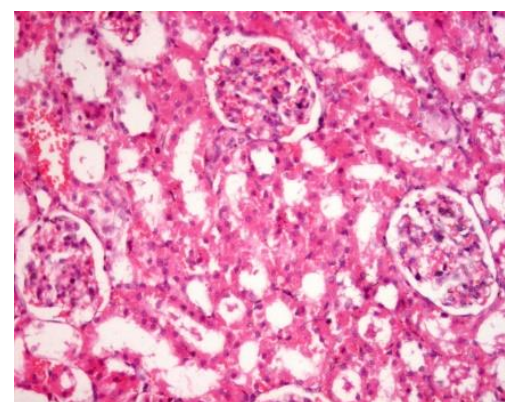

Fig (8): Photomicrograph of rat kidney of the ribavirin/sofosbuvir mixture group showing the normal architecture of the liver (H/E. X200)

\section{AgNORS:}

AgNORs counting of the control liver was 2.11. In ribavirin the count was 2.31. In addition $\mathrm{m}$ the count in sofosbuvir, the count was 2.18 but in mixed the count was 1.91. No significant changes in AgNORs count were observed between groups (figure 9).

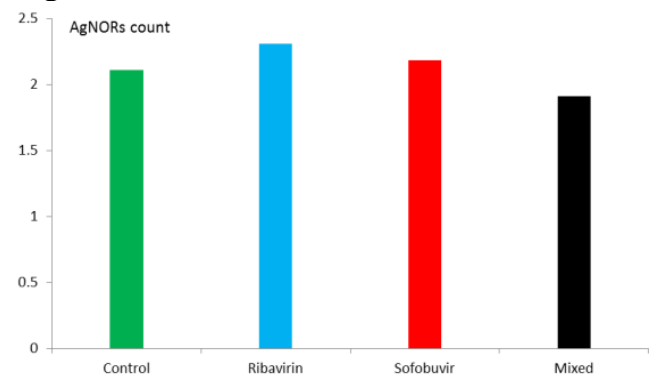

Fig (9): Count of AgNORs in liver of different experimental groups.

\section{Discussion:}

Around $25 \%$ of $\mathrm{HCV}$ cases are selfconstrained resulting in automatic clearance after acute infection, while the rest $75 \%$ of cases advance into chronic disease (Hajarizadeh et al 2013). Up to $33 \%$ of patients with chronic hepatitis C progress liver cirrhosis or potentially hepatocellular carcinoma (HCC) (Hajarizadeh et al 2013; Thomas et al 2013; Ly KN et al 2012). Current treatments of HCV give high cure rates, which are required for development of more powerful therapies (Schmidt et al. 2014). The present study showed that there is no histological damage of liver or kidney due to the treatment with ribavirin and / or sofosbuvir. Many studies evaluated the impact of ribavirin and sofosbuvir on the improvement of inflammation and fibrosis that drive histological benefit and this may 
reduce the rate of fibrosis progression in HCV patients (Mchutchison et al., 1998; Poynard et al., 2002). None of these previous studies examined the histologic effect of direct antiviral drugs such as sofosbuvir and ribavirin. From the present study, the applied treatments with ribavirin $(0.0227 \mathrm{mg} / \mathrm{kg}$ body weight $)$ and sofosbuvir $(0.01 \mathrm{mg} / \mathrm{kg}$ body weight $)$ for 75 days caused no histopathological changes in the liver. Other studies showed long term improvement of some histopathological changes such as inflammation and fibrosis in HCV patients and no adverse effect of both ribavirin and sofosbuvir on the histological structure of the liver (Shiffman et al., 2014). In consistence with the results of the above results of the present study showed that, the number of AgNORs count was normal in all groups of the study as well as no differences in the count were observed between groups. The present study concluded that treatment with sofosbuvir has no side effect on the liver or kidney tissues of rats.

\section{References}

Carithers RL Jr, Emerson SS. (1997): Therapy of hepatitis C: meta-analysis of interferon alfa-2b trials. Hepatology; 26: Suppl 1:83S$88 \mathrm{~S}$.

Crocker, J. and Nar, P. (1987): Nucleolar organizer regions in lymphomas. J. Pathol.; 151: 111- 118.

Detre KM, Belle SH, Lombardero M. (1996): Liver transplantation for chronic viral hepatitis. Viral Hepatitis Rev; 2:219-28.

Drury, R.A.B. and Walligton, E.A. (1967): MaUn Carlton's Histological techniques (Oxford University press) 4th ed, p: 129.

Franchetti P, Cappellacci L, Grifantini M, Senatore G, Martini C, Lucacchini A (1995): Tiazofurin analogues as selective agonists of A1 adenosine receptors. Res Commun Mol Pathol Pharmacol 87:103105.

Grebely J, Prins M, Hellard M, Cox AL, Osburn WO, Lauer G, et al. (2012): Hepatitis C virus clearance, reinfection, and persistence, with insights from studies of injecting drug users: towards a vaccine. Lancet Infect Dis.; 12:408-14.

Hajarizadeh B, Grebely J, Dore GJ (2013). Epidemiology and natural history of HCV infection. Nat Rev Gastroenterol Hepatol.; 10:553-62.

HARVONI_ (ledipasvir and sofosbuvir) tablets, for oral use. (2014): US prescribing information. Foster City: Gilead Sciences.

Holmberg SD, Spradling PR, Moorman AC, Denniston MM. (2013): Hepatitis C in the United States. N Engl J Med; 368: 1859-61.

Hoofnagle JH, Di Bisceglie AM. (1997): The treatment of chronic viral hepatitis. N Engl J Med; 336:347-56.

Institute of Medicine. (2010): Hepatitis and liver cancer: a national strategy for prevention and control of hepatitis B and C. Washington, DC: Nat. Academies Press.

Lemoine M, Nayagam S, Thursz M. (2013): Viral hepatitis in resource-limited countries and access to antiviral therapies: current and future challenges. Futur Virol.; 8:371-80.

Lin R, Roach E, Zimmerman M, Strasser S, Farrell GC. (1995): Interferon alfa-2b for chronic hepatitis $\mathrm{C}$ : effects of dose increment and duration of treatment on response rates: results of the first multicentre Australian trial. J Hepatol; 23:487-96.

Lozano R, Naghavi M, Foreman K, Lim S, Shibuya K, Aboyans V, et al. (2012): Global and regional mortality from 235 causes of death for 20 age groups in 1990 and 2010: a systematic analysis for the Global Burden of Disease Study 2010. Lancet; 380:2095-128.

Ly KN, Xing J, Klevens RM, Jiles RB, Ward JW, Holmberg SD. (2012): The increasing burden of mortality from viral hepatitis in the United States between 1999 and 2007. Ann Intern Med.; 156:271-8.

Manns MP, McHutchison JG, Gordon SC, Rustgi VK, Shiffman M, Reindollar R, et al. (2001): Peginterferon alfa-2b plus ribavirin compared with interferon alfa- $2 b$ plus ribavirin for initial treatment of chronic hepatitis C: a randomised trial. Lancet; 358:958-965.

Martin NK, Vickerman P, Grebely J, Hellard M, Hutchinson SJ, Lima VD. (2013): Hepatitis $\mathrm{C}$ virus treatment for prevention among people who inject drugs: Modeling treatment scale-up in the age of direct-acting antivirals. Hepatology; 58:1598-609.

McHutchinson JG, Gordon SC, Schiff ER, Shiffman ML, Lee WM, Rustgi VK, Goodman ZD, et al. (1998): Interferon alfa$2 \mathrm{~b}$ alone or in combination with ribavirin as initial treatment for chronic hepatitis C. N Engl J Med;339:1485-1492.

Mohd Hanafiah K, Groeger J, Flaxman AD, Wiersma ST. (2013): Global epidemiology 
of hepatitis $C$ virus infection: New estimates of age-specific antibody to $\mathrm{HCV}$ seroprevalence. Hepatology; 57:1333-42.

National Institutes of Health Consensus Development Conference Panel statement (1997): management of hepatitis C. Hepatology; 26: Suppl 1:2S- 10S.

Ochiishi T, Chen L, Yukawa A, Saitoh Y, Sekino Y, Arai T, Nakata H, Miyamoto H (1999) Cellular localization of adenosine A1 receptors in rat forebrain: Immunohistochemical analysis using adenosine A1 receptor-specific monoclonal antibody. J Comp Neurol 411:301-316

Poynard T, McHutchison J, Manns M, Trepo C, Lindsay K, Goodman Z, Ling MH, et al. (2002): Impact of pegylated interferon alfa$2 \mathrm{~b}$ and ribavirin on liver fibrosis in patients with chronic hepatitis C. Gastroenterology; 122:1303-1313.

Reichard O, Norkrans G, Fryden A, Braconier JH, Sonnerborg A, Weiland O. (1998): Randomised, double-blind, placebocontrolled trial of interferon alpha- $2 b$ with and without ribavirin for chronic hepatitis $\mathrm{C}$. Lancet; 351:83-7.

Rivkees SA, Price SL, Zhou FC (1995) Immunohistochemical detection of A1 adenosine receptors in rat brain with emphasis on localization in the hippocampal formation, cerebral cortex, cerebellum, and basal ganglia. Brain Res 677:193-203

Schalm SW, Hansen BE, Chemello L, et al. (1997): Ribavirin enhances the efficacy but not the adverse effects of interferon in chronic hepatitis $\mathrm{C}$ : metaanalysis of individual patient data from European centers. J Hepatol; 26:961-6.

Schmidt WN, Nelson DR, Pawlotsky JM, Sherman KE, Thomas DL, Chung RT. (2014): Direct-acting antiviral agents and the path to interferon independence. Clin Gastroenterol Hepatol.; 12:728-37.

Schvarcz R, Yun ZB, Sonnerborg A, Weiland O. (1995): Combined treatment with interferon alpha-2b and ribavirin for chronic hepatitis $\mathrm{C}$ in patients with a previous nonresponse or non-sustained response to interferon alone. J Med Virol; 46:43-7.

Smith RA, Wade M (1986) Ribavirin: a broad spectrum antiviral agent. In: $\mathrm{T}$ Stapleton (ed) Studies with a broad spectrum antiviral agent. Royal Society of Medicine Services, London, pp. 99-118.

SOVALDI_(sofosbuvir) tablets (2014), for oral use. US prescribing information [revised]. Foster City: Gilead Sciences, Inc.

Thomas DL. (2013): Global control of hepatitis $\mathrm{C}$ : where challenge meets Opportunity. Nat Med.; 19:850-8.

Tine F, Magrin S, Craxi A, Pagliaro L. (1991): Interferon for non-A, non-B chronic hepatitis: a meta-analysis of randomised clinical trials. J Hepatol; 13:192-9.

Yehia BR, Schranz AJ, Umscheid CA, Lo Re V. (2014): The treatment cascade for chronic hepatitis $\mathrm{C}$ virus infection in the United States: a systematic review and meta-analysis. PLoS One.; 9:e101554.

\title{
عنوان البحث: دراسة نسيجية علي تأثيرات والسوفوسبوفير والريبافيرين على الجردان الطبيعية
}

\author{
جمال عبدالرحيم عبدالله ، قدري البكري، نجلاء العربانى، سيق التمتام \\ قسم علم الحيوان- كلية العلوم- جامعة دمياط
}

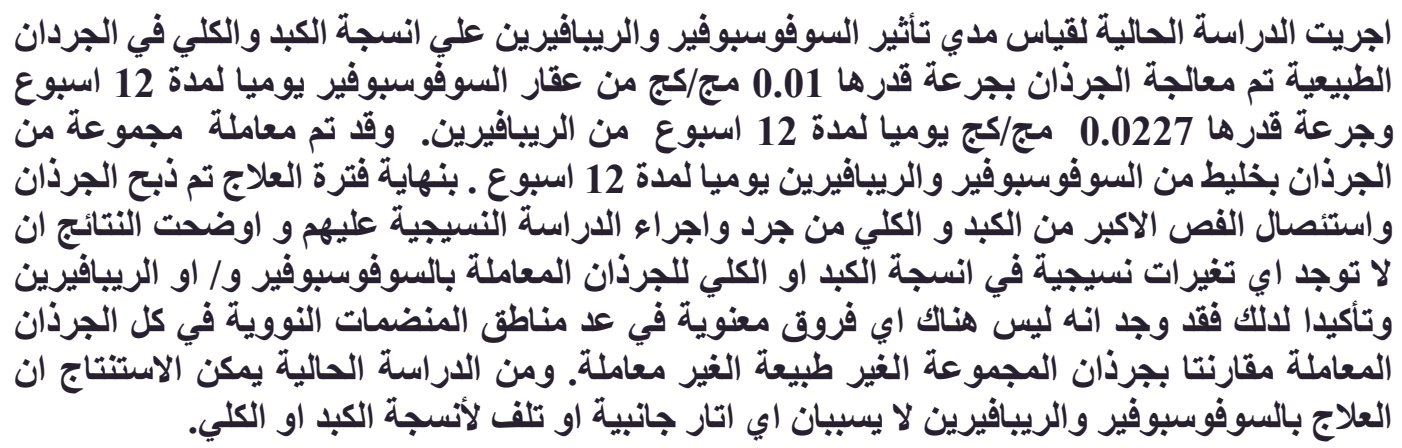

